\title{
Workforce Composition of Public R\&D and Performance: Evidence from Korean Government-Funded Research Institutes
}

\author{
Sangyun Han ${ }^{1}$, Soo Kyung Park ${ }^{2}$ and Kyu Tae Kwak ${ }^{3, * \mathbb{D}}$ \\ 1 Department of International Commerce, Daejeon University, Daejeon 34520, Korea; syhan@dju.ac.kr \\ 2 Graduate School of Information, Yonsei University, Seoul 03722, Korea; sk.park@yonsei.ac.kr \\ 3 Department of Global Culture Industry, Soonchunhyang University, Asan 31538, Korea \\ * Correspondence: ktkwak@sch.ac.kr
}

check for updates

Citation: Han, S.; Park, S.K.; Kwak, K.T. Workforce Composition of Public R\&D and Performance: Evidence from Korean Government-Funded Research Institutes. Sustainability 2021, 13, 3789. https://doi.org/ $10.3390 /$ su13073789

Academic Editor: Lorenzo Ardito

Received: 2 March 2021

Accepted: 25 March 2021

Published: 29 March 2021

Publisher's Note: MDPI stays neutral with regard to jurisdictional claims in published maps and institutional affiliations.

Copyright: (c) 2021 by the authors. Licensee MDPI, Basel, Switzerland. This article is an open access article distributed under the terms and conditions of the Creative Commons Attribution (CC BY) license (https:// creativecommons.org/licenses/by/ $4.0 /)$.

\begin{abstract}
How do the organizational attributes of public R\&D organizations affect their performance? Recent researchers have focused on the relationship between $R \& D$ investments and performance or efficiency, and others suggest that performance may be affected by organizational factors. However, we focus on the attributes of R\&D workforce excellence and diversity of R\&D workforce, which can affect the performance of public R\&D organizations. Therefore, we conduct a panel negative binomial regression and a focus group interview after empirical analysis to derive interpretations and implications. The results show that the effects of the diversity and excellence of an R\&D workforce can vary depending on the type of performance: scientific, technological, or social. Overall, we call for a human resources and resource-based approach to consider the importance of R\&D workforce composition, specifically diversity and excellence, in evaluating the performance of public R\&D organizations.
\end{abstract}

Keywords: workforce composition; public R\&D; performance; government-funded research institutes; resource-based view

\section{Introduction}

Research and development (R\&D) investment in science and technology is essential for both developed and developing countries, because science and technology boost economic growth by providing fundamental assets for technological innovation [1]. For this reason, governments have established and operated government-funded research institutes (GFRIs) - public R\&D organizations dedicated to research on innovation such as strategic technology development for economic growth and science and technology advancement [2]. In general, the role of GFRIs is to correct market failures, including the high investment risks faced by $R \& D$ units in firms and investment avoidance caused by uncertainties in return on investment. In most cases, GFRIs aim to accumulate knowledge on basic science at a national level [3] and to strategically conduct special studies on applied research and development that are essential but not yet chartered by R\&D units in firms. Each government has its own motivations and systems for operating GFRIs, but overall, they recognize the institutes as significant enablers of accumulating basic science and technology knowledge in the early stage of a nation's economic growth [3]. Thus, countries have expanded their GFRI investments and scales. However, due to the global economy and the global recession, governments have sometimes had to reduce their GFRI budgets, creating more competition among institutes that rely on these limited public funds [4]. Furthermore, as the demand increased for public-sector innovation [5], competitive resource allocation and performance evaluation became essential for GFRIs to survive [6].

Many researchers have investigated and discussed resource allocation strategies and performance of private and for-profit organizations through the resource-based view (RBV): According to the RBV, firms effectively allocate and combine strategic resources that are 
valuable, rare, and difficult to imitate or substitute to enhance their performance [7]. However, there are too few studies on public R\&D organizations. To identify and evaluate the antecedent factors of GFRI performance, it is necessary to understand the attributes of these organizations [8]. First, GFRIs are knowledge producers, so they are highly dependent on human resources; it is fundamental for them to secure human resources with excellent competencies for knowledge creation. These organizations need individuals who can produce high-level, innovative, intellectual output to create value and deliver knowledge $[9,10]$.

However, similar to studies on R\&D units in firms, previous studies on GFRIs have focused more on exploring perceived factors at the individual or employee level and on recommending human resource management strategies [11]. Even though management becomes relevant after human resources are secured, there has not been sufficient research on the compositions of workforce teams. Although some researchers have addressed strategies for composing the R\&D workforce, they mostly focus on the workforce composition rather than the workforce diversity, and the results are inconsistent [12].

Second, methods of measuring GFRI performance differ from methods for evaluating private firms; unlike private firms, public institutions such as GFRIs have organizational goals and emphasize mission over profitability, which makes it difficult to define their performance from the perspective of the economic view $[4,8]$. For this reason, there are few academic studies on measuring GFRI performance. Furthermore, measuring methods vary depending on whether the research objective is scientific, academic, technological, financial, or commercial performance, and they utilize different performance indicators [13].

Korea established GFRIs in 1966 and allocates a significant amount of its R\&D budget to these institutes. As of 2019, 25 GFRIs are operating with 15,801 employees, accounting for $22.7 \%$ of the government R\&D budget-about 39.3 billion US dollars per year. Over the past 50 years, Korean science and technology GFRIs have been critical in implementing government-led economic growth strategies centered on developing science and technology.

In this context, many Korean researchers have conducted studies on the determinants and efficiency of GFRIs' research results. These studies have mainly focused on evaluating GFRIs' efficiency and evaluating how these institutes evaluate their own performance. Despite the political importance of GFRIs, studies have been infrequent and limited in scope owing to limitations in detailed data regarding workforce composition, performance, etc. Hence, we examine the effect of organizational attributes of GFRIs on performance. This study was conducted on the basis of a mixed-method analysis [14]. First, a quantitative empirical study was conducted. A balanced panel data sample from 19 Korean GFRIs in science and technology is the setting for investigating the hypotheses proposed in this research. Second, a qualitative study was conducted to contain the opinions of GFRI researchers. We conducted a focus group interview of 24 GFRI researchers to strategically examine their performance and perceptions of workforce compositions and distributions.

This research will contribute to better understanding the workforce composition in public R\&D organizations. In other words, by focusing on the R\&D workforce composition, we can better assess how employee excellence and diversity of R\&D workforce affect the GFRI's performance. For researchers, this study will help them to uncover the effect of two R\&D workforce composition dimensions, excellence and diversity of R\&D workforce, which many researchers were not previously able to explore. This research also adds and provides a strategic managerial implication for R\&D organizations such as GFRIs' employment, and public R\&D organization constructs a differentiated approach to manage the excellence and diversity in their R\&D workforce.

\section{Literature Review and Hypotheses}

To build the foundation of the study, we conducted a literature review of academic discussions on the attributes of public R\&D organizations and performance. 


\subsection{Workforce Composition on RED Performance}

According to the RBV, human resources have some advantages in strategic competitiveness compared with other internal resources, including financial, technical, and organizational [7]. This is because human resources enable collective learning, which is necessary for problem solving, and have the core competence to integrate and coordinate other organizational resources [7].

Previous researchers have mainly focused on perceived impacts of individual employeelevel factors on R\&D performance, analyzing employees' job satisfaction, perceptions of performance factors, internal motivations, empowerment, and attitudes toward leaders [5]. However, relatively few investigators have analyzed the workforce compositions and demographics of research units that directly affect the performance of $R \& D$ organizations $[12,15]$. In particular, there are not enough about the characteristics of workforces in public research organizations that focus on strategic technology development and application [16].

A review of organizational demography, the manpower of R\&D organizations, or "the composition of a social entity in terms of its members' attributes" [17] (p. 303), is an important starting point for understanding the workforces of R\&D organizations. This is because organizational demography provides critical information on the aggregate-level compositions that affect individual-level attributes. For instance, R\&D organizations show human resources with task-related competencies as well as homogeneity and heterogeneity across workforce compositions [12,15]. Therefore, when measuring the excellence and diversity of human resources who demonstrate problem-solving skills and create innovative outcomes, understanding demographics still lays a foundation for effective discussions [18]. Accordingly, some studies analyzed strategies and performance according to employee groups. For example, it has been identified that the characteristics (CEO, employees in R\&D department, organizational status) and roles within organizations responsible for innovation influence the performance of the organization $[19,20]$.

In general, performance of R\&D organizations is driven by their human capital, which is measured by employees' competencies $[7,18]$. This is because employees with high competencies have skills and knowledge necessary for solving problems and are better able to meet their job demands both internally and externally [7]. Thus, for R\&D organizations that need to produce high-level intellectual output to create innovative knowledge, their initial task is to recruit and utilize human resources with excellent research competencies [9]. More specifically, in terms of the organizational composition aspect, the R\&D workforce is divided into full-time and part-time. In general, full-time researchers have more knowledge and know-how, and higher responsibilities [17,21,22]. A higher education level of an R\&D workforce also enables better knowledge and skills, thereby contributing more to improving performance of R\&D personnel [23]. Related to this, OECD provides a measure of national innovation in Main Science and Technology Indicator (MSTI), which investigates the ratio of full-time and Ph.D. researchers. In addition, depending on the importance of these indicators, OECD also included these two indicators in Fascati manual, which measures the input, output, and outcome of R\&D from the perspective of innovation in national level [24]. However, not only human capital competencies, such as employee education levels and work experience, but also those of the social capital that human workforces accumulate both directly and indirectly affect organizations' R\&D performance. In details, researchers' academic and practical experience are also crucial. Recent intensification of global competition and the reduction of technology life cycle require more information related to the market and collaboration based on networks [25]. Therefore, researchers with foreign degrees, with more understanding of the diverse cultural and technological context and a broader researcher network, can produce better performance results. For this reason, it has been considered essential for R\&D organizations to recruit, secure, and maintain Ph.D. personnel who have excellent research capabilities [26], researchers who have received advanced education from overseas universities $[27,28]$, and researchers who have long-term experience and know-how in their fields $[29,30]$. 
Performance of R\&D organizations is also affected by diversity of organizational composition [31]; the more diverse the workforce, the better the understanding of different perspectives and the more knowledge that can be accumulated. For instance, gender diversity can prevent organizations from making homogeneous decisions and create synergy effects in solving problems [32,33]. Additionally, age diversity can contribute to expanding social capital [12], and job and knowledge diversity can have positive impacts on combining knowledge, which is already confirmed by empirical studies [34]. From the information decision-making perspective, diversity nurtures problem-solving skills, because it enhances communication within the organization, creating new ideas internally, and introducing new ideas from the outside [12]. However, from the social categorization perspective, increasing heterogeneity between employees can diminish cohesiveness of the organization and cause conflict among the members [35]. This demonstrates that the results of previous studies on the correlation between diversity and R\&D performance are inconsistent.

\subsection{Measuring RED Performance of GFRIs}

Organizational performance can be defined as the extent to which organizations achieve their objectives or missions [36], and many studies have investigated the definition, measurement, and indicators of organizational performance, but do not provide a clear or consistent result [29]. Previous researchers have measured short-term efficiency compared with long-term effectiveness depending on the timing of the performance [27] and have adopted various performance indicators including productivity, efficiency, innovation, social value, demand from outside organizations, contribution to science and technology development, and customer satisfaction [4], depending on the subject of evaluation. Moreover, they have selectively focused on scientific, academic, technological, financial, or commercial performance, depending on the type of research. For instance, Brown and Svenson identified (1) internal measures, (2) focus on behavior rather than outcomes, (3) complicated measurement methods, and (4) subjective measurement as the main complications of evaluating R\&D performance [37] (p. 109). Moreover, Ojanen and Vuola emphasized that researchers should apply different performance indicators and measurements based on different R\&D types, R\&D analysis levels, and phases [38].

Unlike R\&D units in firms, the primary goal of the public R\&D institutes is neither profit generation nor product development [39]. Their mission is to produce a research outcome that serves public interests, such as science and technology advancement, to solve national or industrial problems, or to set an industry standard [5]. While implementing this mission, they produce research papers, books, innovative prototypes, and patents, and they transfer technology by providing consultation to firms and training programs [29]. In particular, GFRIs' objectives are constantly affected by government policies reflecting the demand and changes of the national and social environment. Therefore, unlike R\&D unit in firms, GFRIs' performance must regard whether the purpose of each institute is achieved and whether it can provide evidence that is comparable with other research institutes [8]. So far, there have been only a few studies on investigating the determinants of GFRIs' performance rather than considering performance measurement methods and variables that reflect the organizational attributes of GFRIs.

Meanwhile, Coccia conducted an empirical study of R\&D performance of public R\&D labs in Italy and utilizes RELEV (research laboratories evaluation) methodology, which takes a systemic approach. Coccia evaluated the performance of the institutes in three categories, financial, technological, and scientific, and used four indexes to measure the research activities: financial (public resources dependency and self-financing), tacit technological transfer (training and teaching activity), bibliometric (national publications), and technological (patents). Coccia's approach is useful for comparing public research institutes with different purposes and has been widely accepted by academia as an empirical method of evaluating the performance of public R\&D organizations [4]. 


\subsection{Hypotheses Development}

We investigated the impact of R\&D workforce composition, a strategic asset of public R\&D organizations, on their performance. To do this, we first divided the characteristics of workforce composition, which contributes to solving problems and creating successful outcomes, into excellence and diversity [40]. In this study, excellence refers to internal research capabilities or expertise of workers who conduct R\&D tasks $[9,18]$, while diversity means appropriate composition of research units that contribute to collective learning and knowledge creation [31,41]. Based on the theoretical discussion earlier, we used share of Ph.D. researchers, full-time researchers, and researchers with international degrees (researchers who have received advanced education from overseas universities) as the excellence of $R \& D$ workforce, and age, gender, and $R \& D$ jobs were used as diversity factors.

We measured the R\&D performance of GFRIs using the revised RELEV method [4], which divides performance into financial, scientific, and technological, and tactic technology transfer adopts performance indicators for each category. We excluded the financial index, because it does not relate directly to GFRI performance of GFRIs and is not easily changed by the efforts of organizations. We also changed the tacit technological transfer index to the social index to reflect its more public nature. In the RELEV method proposed by Coccia, the index of tacit technological transfer is actually divided into the capacity for tacit transfer of knowledge to the beneficiaries and teaching activity of a research organization. In other words, transfer of knowledge produced by R\&D organizations to external beneficiaries is one of the social roles and contributions of public R\&D organizations as missions of GFRIs [4]. However, the capacity for tacit transfer of knowledge to the beneficiaries is the organization's capacity to deliver results, rather than a final GFRI performance. Thus, this study considered the transfer of knowledge by GFRI to diverse external beneficiaries such as SMEs, operated by public funding, as the achievement of social responsibility. In fact, Korean government sets technology transfer as one of GFRIs ${ }^{\prime}$ social roles and missions. Consequently, the transfer of knowledge is used as a performance evaluation criterion for GFRIs in this paper.

Specifically, for the composition and measurement of sub-factors of R\&D performance, the metric considers "internationally acclaimed academic publications" to be a sub-factor of scientific performance; "international patent applications" to be technological performance; and "technology transfer" to be social performance.

\subsubsection{Workforce Excellence and GFRIs' Performance}

Stable tenure enhances job involvement [42], job knowledge, and work routines [9], which ultimately helps each employee grows their expertise and skills [43]. Furthermore, recruiting full-time instead of part-time employees can reduce expenses in training, decreasing costs significantly [44]. Whether a researcher is a full-time regular employee or not, we can infer that a full-time regular researcher holds more responsibility than a part-time R\&D employee [22]. Therefore, we considered hiring full-time, regular employees to be human capital investment [30,44]. Above all, a permanent contract can increase job stability, attracting highly talented personnel to $R \& D$ organizations [29]. There is insufficient research regarding the directionality of this causal relationship, but Guan, Zuo, Chen, and Yam noted that increasing the number of full-time equivalent researchers enhanced R\&D performance [45]. Thus, this study assumes that a higher share of full-time regular employees enhances $R \& D$ performance.

Hypothesis 1 (H1). GFRIs with more regular researchers achieve greater RED performance (scientific, technological, and social) than do those with fewer regular researchers.

Employee job skills and expertise are essentials for R\&D performance [26]. For this reason, public research institutes have a higher tendency to recruit highly educated employees and utilize them to create value and transfer knowledge than do other organizations [10]. Leaders of such institutes believe that employees with the highest education levels perform 
R\&D better than do employees with less education [46]. Education is a key variable in human capital theory, and it represents explicit knowledge that is necessary for task performance [9]. The highest level of education, the Ph.D. level, is known to contribute to job involvement [42], fast learning, problem solving, and creating innovative outcomes [47]. Thus, when there are more members with strong cognitive desire, individual levels of human capital increase $[29,30]$, enhancing the R\&D performance. Particularly, increasing the number of employees with a high education level enhances academic (Science Citation Index, SCI, papers) more than technological (patent applications) performance [37,47]. Thus, we proposed the second hypothesis as follows:

Hypothesis 2 (H2). GFRIs with more Ph.D. researchers achieve greater RED performance (scientific, technological, and social) than do those with fewer Ph.D. researchers.

Hiring researchers who can access external sources of knowledge is one of the essential factors that affect $R \& D$ performance [27]. R\&D performance is often directly related to organizational openness to new ideas and problem-solving methods as well as social capital expansion [28]. Furthermore, hiring employees with international experience provides a competitive edge in globalizing R\&D performance [48]. It helps the organization not only overcome cultural gaps, but also increase its learning capacity to enter the international market. For example, researchers who received Ph.D. or master's degrees from overseas universities can have broad international research networks, and their colleagues can benefit from these networks to publish in international journals and register international patents. Thus, we developed the following hypothesis:

Hypothesis 3 (H3). GFRIs with more researchers with foreign degrees achieve greater RED performance (scientific, technological, and social) than do those with fewer researchers with foreign degrees.

\subsubsection{Workforce Diversity and GFRIs' Performance}

As we discussed above, diverse workforces can support collective learning by helping organizations consider various perspectives and enjoy an abundant amount of knowledge and information [12]. In contrast, some argue that diversity can increase heterogeneity within organizations, diminish solidarity, and cause conflict [35,43]. However, in the case of GFRIs in Korea, because the Korean government is promoting diversity as its policy agenda, we prioritized the positive effects of organizational diversity when we formed our hypothesis. We interpret and discuss contradictory results separately.

First, age is an important variable for social category diversity [49]. When age diversity is high, the organization or team can secure social capital easily through the internal and external relationships of employees in different age groups [12]. Hence, it can enhance performance, because it allows for combining different types of information, technology, and experience. Furthermore, age diversity created a complementary effect between older and younger employees [50]. Therefore, we proposed that age diversity can improve the R\&D performance of GFRIs:

Hypothesis 4 (H4). GFRIs with high age diversity achieve greater RED performance (scientific, technological, and social) than do those with less age diversity.

Gender diversity is one of the most controversial performance indicators [35,51]. Some argue that it can contribute to creating innovative outcomes by increasing social interactions among employees, but studies based on social identity theory or similarityattraction discrimination have concluded that it can increase employee conflict and thereby negatively affect performance [15]. However, from the empirical perspective, there are many empirical and theoretical studies showing that the effect of gender diversity on performance is positive $[12,33,52]$. Faems and Subramanian found that R\&D manpower, 
educational, and gender diversity have substitutive relationships [12]. Thus, we proposed that gender diversity enhances R\&D performance of GFRIs:

Hypothesis 5 (H5). GFRIs with high gender diversity achieve greater RED performance (scientific, technological, and social) than do those with less gender diversity.

Lastly, organizational diversity in organizations bring heterogeneous workforces to creative problem-solving tasks [53,54]. Therefore, organizations promote diversity to expand their problem-solving capacities by combining and sharing the varied knowledge, experiences, and perspectives of their members. Job diversity of public research institutes can be considered from this perspective; increasing the complexity of tasks or responsibilities can strengthen the correlation between diversity and performance [55]. Indeed, $R \& D$ can be effectively operated through diverse employee types. OECD categorizes R\&D workforces by task as researchers, technicians, and supporting staff [24]. Hence, diversified $R \& D$ tasks that best fit organizational attributes improve $R \& D$ performance:

Hypothesis 6 (H6). GFRIs with high job diversity achieve greater RED performance (scientific, technological, and social) than do those with less job diversity.

\section{Research Methods}

\subsection{Quantitative Empirical Study}

We used data sets with budget and workforce composition information on Korean science and technology GFRIs for the eight years from 2010 to 2017 at the institute level, which we obtained from a public institution open information system and from a GFRI statistics information service. The data used in the empirical analysis are based on eight years of data from 19 GFRIs, because six of the 25 GFRIs had errors or missing data. There were a total of 152 final observations.

The dependent variables for measuring performance are each institute's annual number of SCI papers, Patent Cooperation Treaty (PCT) applications, and technology transfers. In this case, empirical analysis was possible with the Poisson distribution model, but the mean and variance would have to be the same according to the definition of the model. However, for our data, we found in the descriptive statistics that the dependent variables had unobserved heterogeneity that is, over-dispersion. So the poisson regression is not effective for analyzing over-dispersed data sets [56].

Therefore, we used the negative binomial distribution model, which includes heterogeneity unobserved in random samples, allows heteroscedasticity, and generalizes the Poisson distribution model.

We examined the following multiple panel linear regression model for institute $i=1 \sim N$, which is observed at each year, $t=1 \sim T$. Here, $y_{i t}$ is the dependent variable, $x_{i t}$ represents the control variables excluding the constant, $\alpha$ is the intercept, $\beta$ and $\gamma$ are parameters, $u_{i}$ is an unobservable individual and institute-specific effect as a time invariant, and $\varepsilon_{i t}$ is an idiosyncratic error term. We also used two variables, excellence and diversity, for the composition of R\&D workforces in GFRIs:

$$
y_{i t}=\alpha_{0}+\sum_{i=1} \beta_{i} X_{i t}+\sum_{i=1} \gamma_{i} \text { CompositionofRDWorkforce }_{i t}+\text { dummy_year }+u_{i}+\varepsilon_{i t}
$$

\subsubsection{Dependent Variables}

GFRIs typically focus on publications, patents, and technology transfers as important indicators of performance, because these are linked to their institutional objectives, unlike in for-profit firms. In fact, the Korean government has used these indicators to evaluate GFRIs' performance, and Coccia also utilized the RELEV method to evaluate the performance of public R\&D organizations [4].

Following this line of reasoning, we set the three different dependent variable categories, scientific, technological, and social, to indicate GFRI performance, in contrast with 
many other researchers who measured financial performance such as firms' returns on assets, growth of sales, total sales from innovations, and other traits to reflect innovative performance from R\&D or training investments [13]. First, for the scientific performance, we measured GFRI performance as the number of published SCI and Science Citation Index Extended (SCIE) articles in a given year (e.g., [57]) by Clarivate Analytics.

The second dependent variable was the number of PCT applications to indicate GFRIs' technological performance. The PCT is an international treaty administered by the World Intellectual Property Organization (WIPO) that makes it possible to seek patent protection for an invention simultaneously in a large number of countries by filing a single international application with a single patent office [58]. Patents reflect technological knowledge and are valid and robust indicators of knowledge creation [59,60]. Moreover, the patent application and examination process can also reflect the external validity of novel inventions [61] in that the process, which is costly, represents a positive expectation by inventors of the economic significance of their inventions [61]. For these various reasons, patents are a reliable and valid measure of $R \& D$ performance in research organizations including for-profit firms [61]. Thus, we used the number of PCT applications to measure GFRIs' technological performance.

The third dependent variable was technology transfer performance. According to Roessner, technology transfer can be defined as "the movement of know-how, technical knowledge, or technology from one organizational setting to another" [62]. Many researchers have regarded technology transfer as a role of GFRIs and universities [63]. Over the last decade, the Korean government has emphasized the technology transfer role of GFRIs, and their mission shifted from just research and development to the aspects of innovative knowledge producers.

\subsubsection{Independent Variables}

We assumed that a GFRI's performance depends on the quality of its researchers, and as such, to assess the effects of R\&D workforce excellence on GFRI performance, we used three independent variables, namely, share of regular researchers, share of Ph.D. researchers, and share of foreign degrees. Regarding full-time employment, we assumed that full-time researchers hold more responsibility than do part-time R\&D employees [22], and thus we used the share of regular research employees to total R\&D employees. We also considered that higher-level academic degrees can significantly improve the performance of GFRIs and that researchers who received higher-level degrees from overseas universities can have broad international research networks that can expand researchers' opportunities to publish in international journals and register international patents.

Another independent variable is GFRIs' workforce diversity. In this study, we used three different diversity variables, age, gender, and job composition of R\&D workforce; job composition reflects that different GFRI employees have different types of knowledge, information, and technology depending on their different tasks. For job composition, OECD defines types of R\&D employees as follows [24]. Researchers are professionals engaged in conceiving or creating new knowledge; they conduct research and improve or develop concepts, theories, models, techniques, instrumentation, software, or operational methods and are typically directly involved in managing R\&D projects. We adopted this OECD definition to measure R\&D job diversity of GFRI workforces, dividing the employees into researchers, technicians, or supporting staff based on their tasks.

To measure the different types of diversity, we used Blau's index of heterogeneity, $1-\sum p_{i}^{2}$ [64], where $p$ is the proportion of a group in the ' $i^{\prime}$ th category. In addition to using Blau's index, diversity can be measured in ways such as dividing the standard deviation by the mean, which is a method for obtaining a scale-invariant measure of dispersion that can usually measure the characteristics of interval-level variables. However, because our data set comprised categorical variables, we used Blau's index to measure the GFRI employees' age, gender, and R\&D job diversity. 


\subsubsection{Control Variables}

Previous literature suggested that both general and specific organizational attributes might affect performance and thus need to be controlled for systematically [65]. Therefore, we controlled for GFRI age, size, and type of R\&D activity, which are often linked to GFRI performance, and we measured GFRI age as number of years elapsed since the year of establishment. We used three separate organizational values to calculate GFRI size: total number of employees, labor cost per employee, and total budget $[16,66]$. To control for the attributes of each GFRI's R\&D activity, we measured R\&D activity type as a variable. As we discussed above, each GFRI has an R\&D activity type, such as basic science or applied research, under its own institute mission and the law. Therefore, we used a dummy variable that took the value of 1 if a GFRI focused on basic science research and was classified under the law related to GFRIs and 0 otherwise. For confirmation, we also calculated the ratio of R\&D investment in basic science research, which matched the previous classification.

\subsection{Qualitative Study}

\section{Focus Group Interview Design}

To derive interpretations and implications from quantitative analysis, we conducted focus group interviews after the empirical analysis. From June to July 2019, interviews with 24 researchers were conducted, based on gender, employment status (full-time or not), and years of service (Table 1). The interviews comprised four stages: (1) opening questions, (2) introductory and transition questions, (3) key questions, and (4) ending questions [67]. For the opening questions, we asked about their current workforce compositions, exploring the interviewees' general perceptions. Then, we asked introductory and transition questions to help the interviewees prepare for the key question by allowing them to freely express their opinions about the impacts of their workforce compositions on their organizations' performance.

Table 1. Characteristics of Participants.

\begin{tabular}{|c|c|c|c|c|c|c|c|}
\hline Code & Age & Gender & $\begin{array}{c}\text { R\&D } \\
\text { Occupation }\end{array}$ & $\begin{array}{l}\text { Year of } \\
\text { Service }\end{array}$ & R\&D Field & $\begin{array}{l}\text { Employment } \\
\text { Status }\end{array}$ & $\begin{array}{c}\text { Final } \\
\text { Degree }\end{array}$ \\
\hline A1 & $60 \mathrm{~s}$ & Male & PM & 25 & Chemistry & Regular & 1 \\
\hline B1, B2, B3 & $50 \mathrm{~s}$ & Male & PM & 15 & $\begin{array}{c}\text { Aerospace, Mechanical } \\
\text { Engineering }\end{array}$ & Regular & 2 \\
\hline $\mathrm{C} 1, \mathrm{C} 2$ & $50 \mathrm{~s}$ & Female & PM & 15 & Physics, Electronics & Regular & 1 \\
\hline D1, D2 & $50 \mathrm{~s}$ & Male & Researcher & 10 & Mathematics, IT & Regular & 1 \\
\hline E1, E2 & $40 \mathrm{~s}$ & Male & Researcher & 3 & Chemistry, Bioscience & Regular & 2 \\
\hline $\mathrm{F} 1, \mathrm{~F} 2$ & $30 \mathrm{~s}$ & Female & Researcher & 3 & $\begin{array}{l}\text { Geology, Electrical } \\
\text { Engineering }\end{array}$ & Regular & 1 \\
\hline G1, G2 & $30 \mathrm{~s}$ & Male & Researcher & 3 & Aerospace, IT & Irregular & 1 \\
\hline $\mathrm{H} 1, \mathrm{H} 2$ & $40 \mathrm{~s}$ & Male & Researcher & 3 & $\begin{array}{l}\text { Electronics, Electrical } \\
\text { Engineering }\end{array}$ & Irregular & 2 \\
\hline $\mathrm{I} 1, \mathrm{I} 2$ & $30 \mathrm{~s}$ & Female & Researcher & 3 & $\begin{array}{l}\text { Bioscience, Material } \\
\text { Engineering }\end{array}$ & Irregular & 1 \\
\hline $\mathrm{J} 1, \mathrm{~J} 2$ & $30 \mathrm{~s}$ & Male & Technician & 3 & Chemical Engineering & Irregular & 3 \\
\hline $\mathrm{K} 1, \mathrm{~K} 2$ & $20 \mathrm{~s}$ & Female & Technician & 1 & $\begin{array}{l}\text { Chemistry, Electrical } \\
\text { Engineering }\end{array}$ & Irregular & 3 \\
\hline L1, L2 & $30 \mathrm{~s}$ & Female & Researcher & 1 & IT, Electronics & Irregular & 1 \\
\hline
\end{tabular}

Notes: $\mathrm{N}=24$ (Final degree: 1 = Domestic doctorate, 2 = Foreign doctorate (Ph.D. degree achieved at foreign university), $3=$ Domestic master's degree).

We asked the 24 focus group interviewees to analyze the roles of full-time employees, Ph.D. researchers, and researchers with foreign degrees in the three categories of performance and to discuss their perceptions of their organizations' levels of age, gender, and $R \& D$ job diversity. After this stage, we presented the quantitative study results to ask the interviewees for their reflections. The ending questions related to the group members' opinions on the optimal workforce compositions for their organizations' best performance. The interviews took two and a half hours on average. 


\section{Analysis and Results}

\subsection{Quantitative Empirical Study}

Table 2 shows the correlations between variables and descriptive statistics for the variables. For the empirical analysis, we tested the multicollinearity of variables, and the variance inflation factors ranged from 1.56 to 1.92 (average: 1.8), suggesting that multicollinearity of variables was not a problem in our analyses.

Our first empirical analysis, shown in Table 3, related to the impact of GFRI R\&D workforce excellence on each performance variable: the numbers of SCI papers, PCT applications, and technology transfers. First, for H1, the share of regular researchers $(z=2.55$, $p<0.05$ ) had a positively significant impact only on the number of PCT applications among the three performance variables. Next, the share of Ph.D. researchers had a positively significant impact on the number of SCI papers $(z=1.81, p<0.10)$, the number of PCT applications $(z=2.61, p<0.01)$, and the number of technology transfers $(z=2.42, p<0.01)$. Thus, $\mathrm{H} 2$ was supported. This demonstrates that the more highly educated employees at a GFRI, including Ph.D. researchers, the more SCI papers, PCT applications (technological or engineering performance), and technology transfers the institute will possess. Finally, for $\mathrm{H} 3$, the share of employees with foreign degrees $(z=-2.54, p<0.01)$ had a negatively significant impact on the number of technology transfers, demonstrating a lower likelihood that GFRI performance would transfer to recipients in GFRIs with high shares of employees with foreign degrees.

Table 4 shows the impacts of GFRI R\&D workforce diversity on the three types of performance. First, age diversity $(z=2.02, p<0.05)$, related to $\mathrm{H} 4$, had a positively significant impact only on the number of technology transfers. However, the opposite was the case for H5: Gender diversity had a negatively significant impact on the number of SCI papers $(z=-2.39, p<0.01)$ and PCT applications $(z=-1.89, p<0.05)$. Increasing gender diversity had a negative impact on scientific and technological performance. Lastly, $\mathrm{R} \& \mathrm{D}$ job diversity, for $\mathrm{H6}$, showed different results for the different dependent variables, with positively significant impacts on the numbers of SCI papers $(z=2.50, p<0.01)$ and PCT applications $(z=2.00, p<0.05)$ but a negatively significant impact on the number of technology transfers $(z=-2.32, p<0.01)$.

\subsection{Qualitative Study}

4.2.1. Relationship between Excellence of R\&D Workforce and Organizational Performance

The focus group discussions about the excellence of R\&D workforces first focused on the shares of full-time, regular researchers. The project-based system, which began in the late 1990s, is a system in which GFRIs cover the minimum amount of labor and research cost through government funding and procure the remaining capital through project contracts. The system was designed to encourage GFRIs to change their operational structures and to minimize costs by securing research funding. Moreover, as the Korean government's ratio of R\&D budget to its GDP increased over the past 15 years, targeting the highest level of the OECD, its policy changed in 2010 to focus on improving the efficiency of the R\&D budget.

With this change, the government requested that GFRIs' increase the efficiency of their R\&D budgets, and so increased their shares of part-time employees to decrease their labor costs. As a result, part-time employees accounted for about $24 \%$ of total GFRI employees FRIs in Korea as of 2017. This is 10 times higher than that of supporting staff (2.2\%).

Interviewees" opinions about this state of affairs varied from "it can secure the flexibility of human resource management at the organization level" (Interviewee A1) to "it has created an environment where researchers cannot focus on their work due to job insecurity" (Interviewee H2), and responses were similar in the discussions about performance. Similar to the quantitative study result (H1), interviewees supported that increasing shares of part-time employees could affect GFRI performance. 
Table 2. Descriptive Statistics and Correlations.

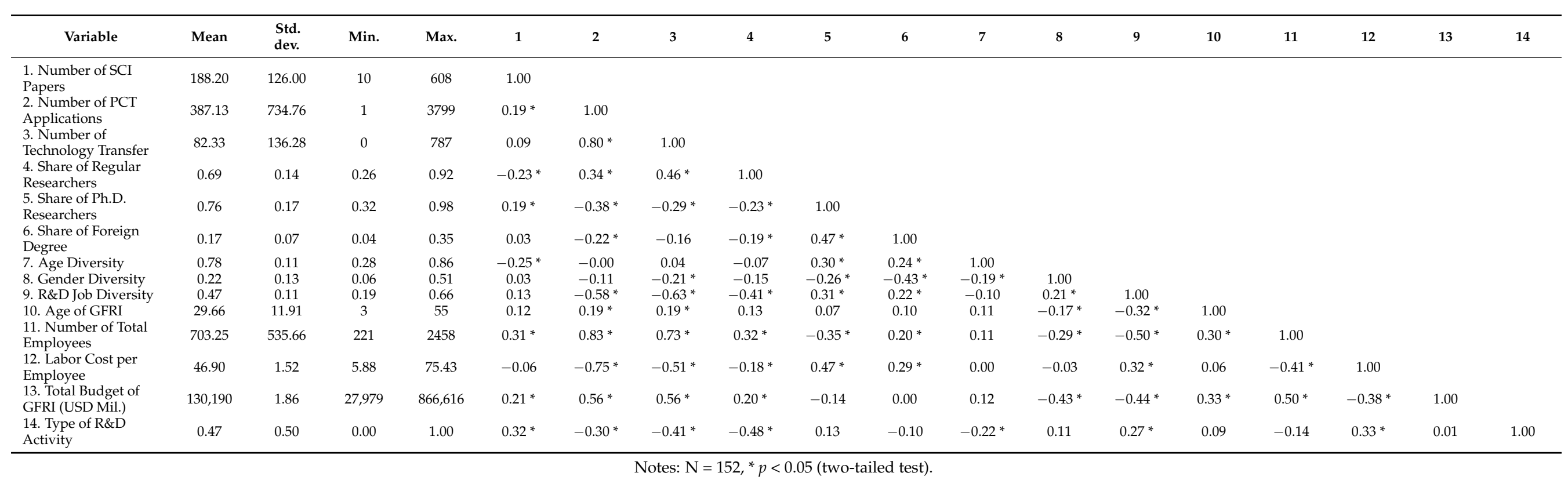


Table 3. Negative Binomial with Fixed Effects Results of the Excellence of R\&D Workforce (H1-H3).

\begin{tabular}{|c|c|c|c|}
\hline \multirow{2}{*}{ Variables } & (Model 1) & (Model 2) & (Model 3) \\
\hline & Number of SCI Papers & $\begin{array}{l}\text { Number of PCT } \\
\text { Applications }\end{array}$ & $\begin{array}{c}\text { Number of Technology } \\
\text { Transfer }\end{array}$ \\
\hline GFRI Age & $0.062^{* * *}(0.019)$ & $-0.024^{* *}(0.01)$ & $0.065^{* * *}(0.016)$ \\
\hline Number of total employees & $0.737^{* * *}(0.251)$ & $1.584^{* * *}(0.213)$ & $0.805^{* * *}(0.312)$ \\
\hline $\begin{array}{l}\text { Labor cost per employee } \\
\qquad(\mathrm{t}-1)\end{array}$ & $-0.023(0.125)$ & $0.877^{* *}(0.368)$ & $0.225(0.162)$ \\
\hline Total GFRI Budget $(t-1)$ & $0.127(0.099)$ & $0.056(0.087)$ & $0.311^{* *}(0.145)$ \\
\hline Type of R\&D activity & $-0.934^{* *}(0.375)$ & $-0.454^{* *}(0.223)$ & $-0.582 *(0.351)$ \\
\hline $\begin{array}{l}\text { Share of regular researchers } \\
\qquad(t-1)\end{array}$ & $0.156(0.63)$ & $1.320 * *(0.517)$ & 1.499 (0.957) \\
\hline $\begin{array}{l}\text { Share of Ph.D. researchers } \\
\qquad(t-1)\end{array}$ & $0.905 *(0.501)$ & $0.667^{* * *}(0.256)$ & $0.474^{* * *}(0.196)$ \\
\hline Share of foreign degree $(t-1)$ & $-0.857(1.153)$ & $-1.328(1.002)$ & $-0.830^{* * *}(0.327)$ \\
\hline Constant & $-5.345^{* * *}(1.781)$ & $-12.480 * * *(2.007)$ & $-11.170 * * *(2.445)$ \\
\hline Year dummies & Included & Included & Included \\
\hline Wald chi-square & $80.09 * * *$ & $150.35^{* * *}$ & $193.70^{* * *}$ \\
\hline Log likelihood & -695.229 & -639.075 & -564.437 \\
\hline LR test vs. pooled & $167.75^{* * *}$ & $117.80^{* * *}$ & $99.62^{* * *}$ \\
\hline Number of Observations & 133 & 126 & 133 \\
\hline
\end{tabular}

Notes: ${ }^{*} p<0.10,{ }^{* *} p<0.05,{ }^{* * *} p<0.01$ standard errors are in parentheses. Labor cost per employee, total GFRI budget, and diversity of $\mathrm{R} \& \mathrm{D}$ workforce variables are lagged by a year. The upper $5 \%$ outliers of data excluded in model 2 .

Table 4. Negative Binomial with Fixed Effects Results of R\&D Workforce Diversity (H4-H6).

\begin{tabular}{|c|c|c|c|}
\hline \multirow{2}{*}{ Variables } & (Model 4) & (Model 5) & (Model 6) \\
\hline & Number of SCI Papers & $\begin{array}{l}\text { Number of PCT } \\
\text { Applications }\end{array}$ & $\begin{array}{c}\text { Number of Technology } \\
\text { Transfer }\end{array}$ \\
\hline GFRI Age & $0.048^{* * *}(0.009)$ & $-0.023 * *(0.009)$ & $0.117^{* * *}(0.016)$ \\
\hline Number of total employees & $0.622 *(0.263)$ & $1.385^{* * *}(0.271)$ & $0.021(0.373)$ \\
\hline $\begin{array}{l}\text { Labor cost per employee } \\
\qquad(\mathrm{t}-1)\end{array}$ & $-0.119(0.107)$ & $0.889^{* *}(0.349)$ & $0.07(0.163)$ \\
\hline Total GFRI Budget $(t-1)$ & $-0.005(0.094)$ & $0.088(0.088)$ & $0.034(0.144)$ \\
\hline Type of R\&D activity & $-0.733^{* *}(0.339)$ & $-0.625^{* *}(0.258)$ & $0.336(0.506)$ \\
\hline Age diversity $(t-1)$ & $-0.953(0.907)$ & $-0.436(0.793)$ & $0.899^{* *}(0.446)$ \\
\hline Gender diversity $(t-1)$ & $-0.999^{* * *}(0.418)$ & $-0.585^{* *}(0.309)$ & $0.468(1.296)$ \\
\hline$R \& D$ job diversity $(t-1)$ & $0.619^{* * *}(0.248)$ & $0.154^{* *}(0.077)$ & $-0.262^{* * *}(0.113)$ \\
\hline Constant & $-4.083 * *(1.655)$ & $-8.895 * * *(2.542)$ & $-14.752^{* * *}(2.443)$ \\
\hline Year dummies & Included & Included & Included \\
\hline Wald chi-square & $85.71^{* * *}$ & $55.98^{* * *}$ & $228.70 * * *$ \\
\hline Log likelihood & -694.000 & -655.105 & -565.291 \\
\hline LR test vs. pooled & $184.18^{* * *}$ & $109.47^{* * *}$ & $87.22 * * *$ \\
\hline Number of Observations & 133 & 126 & 133 \\
\hline
\end{tabular}

Notes: ${ }^{*} p<0.10,{ }^{* *} p<0.05,{ }^{* * *} p<0.01$ standard errors are in parentheses. Labor cost per employee, total GFRI budget, and diversity of R\&D workforce variables are lagged by a year. The upper $5 \%$ outliers of data excluded in model 5 .

The researchers in the focus groups did agree that increasing part-time employees could temporarily increase the numbers of productive R\&D researchers with doctoral degrees or higher, which would increase organizations' capacities to respond to emerging technologies, acquire the latest knowledge, and expand their research networks. However, they also mentioned that when the share of part-time researchers grows, it could negatively affect performance, because it keeps organizations from accumulating research experience and sustainability.

Finally, regarding the correlation between the share of Ph.D. researchers and performance $(\mathrm{H} 2)$, most of the respondents said that it creates a positive impact on R\&D 
performance. However, they had conflicting opinions about the impacts of researchers with foreign degrees. Interviewee B2 positively analyzed that "they play a role of transferring new knowledge within the organization", but D1 and K2 argued that researchers with foreign degrees lack the networks within Korean companies to contribute to transferring research results and distributing knowledge. In other words, in contrast with those who receive their doctoral degrees in Korea, researchers with overseas degrees lack social capital, making it difficult for them to directly contribute to transferring knowledge. From this interview, we can infer the reasons for our finding for $\mathrm{H} 3$.

\subsubsection{Relationship between Diversity of R\&D Workforce and Organizational Performance}

Related to the age diversity, research field, and performance, interviewee C2 said, "in the sectors such as IT and convergence research, where technology is rapidly advancing, younger researchers have higher performance, but in the sectors such as astronomy and geology, know-how accumulated through experience is more critical, which means that there is no significant correlation between age and research performance." In terms of age diversity (H4), most of the interviews responded positively: "Senior researchers complement the lack of experience, research capacity, and research insights of new researchers" (Interviewee E1), confirming the complementary effect between older and younger employees [50] that we discussed earlier. Gender diversity was the topic that interviewees found most difficult to discuss. They analyzed gender diversity considering the research sectors and work culture of each organization and cited conflicts in terms of how organizations conduct research and manage teams (Interviewees B1, C1, H2, I2).

Lastly, regarding R\&D job diversity, most focus group interviewees said that it had a positive impact on performance; with appropriate workforce mixes of researchers, technicians, and supporting staff, each member can focus on their own tasks and create the best outcomes. Specifically, Interviewee B3 said, "to maximize the research outcome, we need technicians and supporting staff members. The research outcome can be changed depending on how much support the research organization receives." However, some interviewees argued that R\&D job diversity is not a priority in the process of creating outcomes, because its correlation with performance may vary by tasks. For instance, Interviewee D2 said, "when there are too many different positions compared to the tasks they perform, the organization may be oversized, causing inefficiency." Based on this interview, we can infer that the reason for the negative correlation between R\&D job diversity and social performance (the number of technology transfers) is that unlike researchers, technicians and supporting staff cannot provide practical help in transferring technology. These findings suggest that composing a workforce based on each R\&D organization's objectives can improve its performance.

\section{Discussion}

Public R\&D organizations have different organizational structures from those of firms, and the objectives of public R\&D organizations relate to scientific and technological rather than financial performance [39]. Therefore, they have uniquely composed workforces.

Based on this difference, this study analyzed how workforce compositions can affect the performance of GFRIs in Korea, which set R\&D itself as their mission, with mixed methods. Specifically, eight years of panel data were constructed from 19 GFRIs in Korea, to empirically examine the effect of excellence and diversity of employees within these organizations on GFRIs' performance. Next, quantitative analysis was followed for indepth interpretation, where two GIs were conducted for 24 researchers working at GFRIs. In particular, this research modified the RELEV method [4] to analyze the performance in three aspects, scientific, technological, and social. Because GFRIs have R\&D as their specific mission, we selected the number of SCI papers to reflect their scientific performance, the number of the number of PCT applications to indicate technological performance, and technology transfer, which is transferring the previous two types of performance to the private sector, to indicate social performance. This conceptual framework reflects that 
GFRI outcomes are not individually segmented, but rather are the integrated result of the R\&D value chain that GFRIs with a public mission pursue.

The results of analyzing the impact of the R\&D Workforce Excellence on GFRIs' performance are as follows. First, we found that the share of regular researchers only had a positively significant impact on the number of PCT applications; therefore, H1 was supported by only one of the three dependent variables. This result also matches with our focus group interview finding that regular researchers with greater responsibility and authority play an important role in improving performance in the long term. Previous research has also confirmed that stable tenure enhances job involvement [42] and increases tacit knowledge and work routines, which in turn enhances employees' skills and expertise [43].

Second, a high share of Ph.D. researchers plays a positive role in increasing the numbers of SCI papers, PCT applications, and technology transfer, which we interpret to reflect that human resources with higher academic excellence contribute more to enhancing performance. In fact, higher education such as doctorate degrees indicates employees' job skills and expertise, the most basic requirements for better performance in R\&D organizations [26]. Particularly, GFRIs employ researchers with high levels of education more than other organizations, and they create value and transfer knowledge through their R\&D employees [10]. In this process, the education level can improve job involvement [42], support fast learning and problem solving, and help the organization achieve innovative outcomes [47]. Indeed, we confirmed this conclusion in two focus group interviews with 24 researchers, who are the targets of empirical analysis on the correlation between the share of highly educated employees and performance.

Contrary to the results above, increasing the share of employees with foreign degrees had a negative impact on technology transfer, which did not support H3. This is because most GFRIs' technologies are transferred to Korean companies, and employees with overseas education have weaker networks across Korean firms. Additionally, whereas most researchers with domestic degrees gain their R\&D experience with Korean firms on national research and development projects during their schooling, researchers with overseas education have less of this domestic experience. Both our empirical analysis and the focus group interviews confirmed that researchers with foreign degrees contributed less to social R\&D performance.

Next, the results of the analysis of R\&D workforce diversity on GFRIs' performance are as follows. First, age diversity (H4) had a positive effect only on technology transfer; in this respect, high age diversity within GFRI workforces had a positive impact on performance, demonstrating a complementary effect of age diversity $[49,50]$, which we identified in the focus group interviews as well; with regard to age diversity, interviewees said that senior researchers complemented the younger researchers' lack of experience, research capacity, and research insights.

Second, higher gender diversity had a negative impact on the number of SCI papers and the number of PCT applications, and previous researchers have addressed this conflict between demographic variables $[15,68]$. Focus group interviewees for this study found the relationship between gender diversity and performance to be the most difficult topic to discuss, not because gender affected research capability, but because it can cause employee conflicts over the long term. Further research is needed to more deeply investigate this relationship.

Finally, R\&D job diversity had a positive impact on the numbers of SCI papers and PCT applications. This means that researchers need supporting staff members to conduct research more efficiently and effectively, following the OECD definition [24]. However, higher R\&D job diversity had a negative impact on the number of technology transfers, which did not support H6. This is because, unlike researchers, technicians and supporting staff members cannot provide practical help in transferring technology.

Theoretical implications based on our major research results are as follows. The first significant implication of this study is that we are the first to analyze the impacts of workforce composition in public R\&D organizations on two aspects of their performance: 
excellence in research capacity and diversity in workforce portfolio. Second, this study is significant because it divided performance into three aspects from the perspective of R\&D value chain, which are the number of SCI papers, the number of PCT applications, and the number of technology transfers, in contrast with previous researchers. Indeed, R\&D workforce excellence and diversity affected each performance aspect differently, and this finding contributes to expanding discussions on diversity, which is emerging as an important topic for organizational research. Third, by utilizing a focus group, a qualitative research method, we could discuss the results of the empirical analysis in detail, expanding discussions and contributing to identifying the role of workforce composition from a new perspective.

This study also provides practical implications. First, in order to enhance organizational performance, not only excellence but also diversity should be considered in workforce composition. Many organizations, including for-profit businesses, emphasize employee excellence, but leaders should also consider the qualitative aspects of workforces such as their diversity. Second, despite the political, technological, and scientific importance of GFRIs, related research has only focused on the input side of performance, such as efficiency. With this study, we emphasize the importance of the quality of human resources, and we suggest two dimensions of workforce composition, excellence and diversity, for practical outcomes. Third, the dimensions have different correlations with the different types of performance. Our findings suggest that ideal workforce composition depends on a GFRI's particular sector, such as basic science or applied research.

Despite the contribution of this study in investigating the factors of GFRIs performance by comprehensively considering both quantitative data on the operation and performance of GFRIs and qualitative data from researchers, the panel data's observation period is rather short and it only considered Korean GFRI in the analysis. Therefore, subsequent research should put more effort into stable data collection and consider various national characteristics. Additionally, future studies should include more microscopic views on the interaction of R\&D workforce excellence (merit) with diversity [40], public innovative leadership contributing to performance [5], entrepreneurship [8], mechanism of inter and intra-governance triggering public innovation [16,39], and more.

Author Contributions: Conceptualization, Formal Analysis, Writing-Original Draft Preparation, S.H.; Data Curation, Writing-Original Draft Preparation, S.K.P.; Validation, Writing—Review \& Editing, Supervision, K.T.K. All authors have read and agreed to the published version of the manuscript.

Funding: This research received no external funding.

Institutional Review Board Statement: Not applicable.

Informed Consent Statement: Not applicable.

Data Availability Statement: Not available.

Acknowledgments: This research was supported by the Korea Institute of S\&T Evaluation and Planning (KISTEP).

Conflicts of Interest: The authors declare no conflict of interest.

\section{References}

1. Vega-Gomez, F.I.; Miranda-Gonzalez, F.J. Choosing between Formal and Informal Technology Transfer Channels: Determining Factors among Spanish Academicians. Sustainability 2021, 13, 2476. [CrossRef]

2. Donaldson, L. The Contingency Theory of Organizations; Sage: Thousand Oaks, CA, USA, 2001.

3. Mazzoleni, R.; Nelson, R.R. Public research institutions and economic catch-up. Res. Policy 2007, 36, 1512-1528. [CrossRef]

4. Coccia, M. A basic model for evaluating R\&D performance: Theory and application in Italy. RED Manag. 2001, 31, 453-464. [CrossRef]

5. De Vries, H.; Bekkers, V.; Tummers, L. Innovation in the Public Sector: A Systematic Review and Future Research Agenda. Public Adm. 2016, 94, 146-166. [CrossRef]

6. Wang, J.; Lee, Y.-N.; Walsh, J.P. Funding model and creativity in science: Competitive versus block funding and status contingency effects. Res. Policy 2018, 47, 1070-1083. [CrossRef] 
7. Barney, J.B.; Wright, P.M. On becoming a strategic partner: The role of human resources in gaining competitive advantage. Hum. Resour. Manag. 1998, 37, 31-46. [CrossRef]

8. Carnes, C.M.; Gilstrap, F.E.; Hitt, M.A.; Ireland, R.D.; Matz, J.W.; Woodman, R.W. Transforming a traditional research organization through public entrepreneurship. Bus. Horizons 2019, 62, 437-449. [CrossRef]

9. Lee, S.-H.; Wong, P.-K.; Chong, C.-L. Human and Social Capital Explanations for R\&D Outcomes. IEEE Trans. Eng. Manag. 2005, 52, 59-68. [CrossRef]

10. Miles, I. Knowledge intensive business services: Prospects and policies. Foresight 2005, 7, 39-63. [CrossRef]

11. Hurley, J. Scientific Research Effectiveness: The Organization Dimension; Kluwer Academic Publishers: Dordrecht, The Netherlands, 2003.

12. Faems, D.; Subramanian, A.M. R\&D manpower and technological performance: The impact of demographic and task-related diversity. Res. Policy 2013, 42, 1624-1633. [CrossRef]

13. Werner, B.M.; Souder, W.E. Measuring R\&D Performance-State of the Art. Res. Manag. 1997, 40, 34-42. [CrossRef]

14. Borowski, P.F. New Technologies and Innovative Solutions in the Development Strategies of Energy Enterprises. HighTech Innov. J. 2020, 1, 39-58. [CrossRef]

15. Bell, S.T.; Villado, A.J.; Lukasik, M.A.; Belau, L.; Briggs, A.L. Getting Specific about Demographic Diversity Variable and Team Performance Relationships: A Meta-analysis. J. Manag. 2011, 37, 709-743. [CrossRef]

16. Buchheim, L.; Krieger, A.; Arndt, S. Innovation types in public sector organizations: A systematic review of the literature. Manag. Rev. Q. 2020, 70, 509-533. [CrossRef]

17. Pfeffer, J. Organizational Demography. Res. Organ. Behav. 1983, 5, $299-357$.

18. Van Esch, E.; Wei, L.Q.; Chiang, F.F.T. High-performance human resource practices and firm performance: The mediating role of employees' competencies and the moderating role of climate for creativity. Int. J. Hum. Resour. Manag. 2016, 29, 1683-1708. [CrossRef]

19. Vosloban, R.I. The Influence of the Employee's Performance on the Company's Growth-A Managerial Perspective. Procedia Econ. Finance 2012, 3, 660-665. [CrossRef]

20. Borowski, P.F. Innovation strategy on the example of companies using bamboo. J. Innov. Entrep. 2021, 10, 1-17. [CrossRef] [PubMed]

21. Pfeffer, J. Barriers to the Advance of Organizational Science: Paradigm Development as a Dependent Variable. Acad. Manag. Rev. 1993, 18, 599-620. [CrossRef]

22. Han, S.Y.; Bae, S.J. Internalization of R\&D outsourcing: An empirical study. Int. J. Prod. Econ. 2014, 150, 58-73. [CrossRef]

23. Mangematin, V.; Nesta, L. What kind of knowledge can a firm absorb? Int. J. Technol. Manag. 1999, 18, 149. [CrossRef]

24. OECD. Frascati Manual 2015: Guidelines for Collecting and Reporting Data on Research and Experimental Development; OECD Publishing: Paris, France, 2015.

25. Beers, C.; Zand, F. R\&D Cooperation, Partner Diversity, and Innovation Performance: An Empirical Analysis. J. Prod. Innov. Manag. 2014, 31, 292-312.

26. Torbeck, L.; Sidhu, R.; Smink, D.S.; Peyre, S.E. How to Recruit, Retain, and Reap the Rewards of Working with PhD/EdD Educators in Surgery. J. Surg. Educ. 2013, 70, 212-216. [CrossRef]

27. Fey, C.F.; Birkinshaw, J. External Sources of Knowledge, Governance Mode, and R\&D Performance. J. Manag. 2005, 31, 597-621. [CrossRef]

28. Hsu, C.-W.; Lien, Y.-C.; Chen, H. R\&D internationalization and innovation performance. Int. Bus. Rev. 2015, 24, 187-195. [CrossRef]

29. Coccia, M. Research performance and bureaucracy within public research labs. Scientometrics 2008, 79, 93-107. [CrossRef]

30. Thompson, M.; Heron, P. Relational quality and innovative performance in R\&D based science and technology firms. Hum. Resour. Manag. J. 2006, 16, 28-47. [CrossRef]

31. Harrison, D.A.; Klein, K.J. What's the difference? diversity constructs as separation, variety, or disparity in organizations. Acad. Manag. Rev. 2007, 32, 1199-1228. [CrossRef]

32. Kanter, R.M. Some Effects of Proportions on Group Life. In The Gender Gap in Psychotherapy; Springer: Boston, MA, USA, 1977.

33. Xie, L.; Zhou, J.; Zong, Q.; Lu, Q. Gender diversity in R\&D teams and innovation efficiency: Role of the innovation context. Res. Policy 2020, 49, 103885. [CrossRef]

34. Taylor, A.; Greve, H.R. Superman or the Fantastic Four? knowledge combination And experience in Innovative Teams. Acad. Manag. J. 2006, 49, 723-740. [CrossRef]

35. Martinez, M.G.; Zouaghi, F.; Marco, T.G. Diversity is strategy: The effect of R\&D team diversity on innovative performance. RED Manag. 2016, 47, 311-329. [CrossRef]

36. Sousa, C.A.; De Nijs, W.F.; Hendriks, P.H. Secrets of the beehive: Performance management in university research organizations. Hum. Relat. 2010, 63, 1439-1460. [CrossRef]

37. Brown, M.G.; Svenson, R.A. Measuring R\&D Productivity. Res. Manag. 1988, 31, 11-15. [CrossRef]

38. Ojanen, V.; Vuola, O. Coping with the multiple dimensions of R\&D performance analysis. Int. J. Technol. Manag. 2006, 33, 279. [CrossRef]

39. Torfing, J. Collaborative innovation in the public sector: The argument. Public Manag. Rev. 2019, 21, 1-11. [CrossRef] 
40. Park, S.; Liang, J. Merit, Diversity, and Performance: Does Diversity Management Moderate the Effect of Merit Principles on Governmental Performance? Public Pers. Manag. 2019, 49, 83-110. [CrossRef]

41. Guajardo, S.A. Assessing Organizational Efficiency and Workforce Diversity: An Application of Data Envelopment Analysis to New York City Agencies. Public Pers. Manag. 2015, 44, 239-265. [CrossRef]

42. Brown, S.P. A Meta-analysis and Review of Organizational Research on Job Involvement. Psychol. Bull. 1996, 120, $235-255$. [CrossRef]

43. Pelled, L.H.; Eisenhardt, K.M.; Xin, K.R. Exploring the Black Box: An Analysis of Work Group Diversity, Conflict, and Performance. Adm. Sci. Q. 1999, 44, 1-28. [CrossRef]

44. Bontis, N.; Fitz-Enz, J. Intellectual capital ROI: A causal map of human capital antecedents and consequents. J. Intellect. Cap. 2002, 3, 223-247. [CrossRef]

45. Guan, J.; Zuo, K.; Chen, K.; Yam, R.C. Does country-level R\&D efficiency benefit from the collaboration network structure? Res. Policy 2016, 45, 770-784. [CrossRef]

46. Pelz, D.C.; Andrews, F.M. Scientists in Organizations: Productive Climates for Research and Development; Revised Edition; Institute for Social Research, University of Michigan: Ann Arbor, MI, USA, 1976.

47. Herrera, L.; Nieto, M. The determinants of firms' PhD recruitment to undertake R\&D activities. Eur. Manag. J. 2015, 33, 132-142. [CrossRef]

48. Johnson, J.; Yin, E.; Tsai, H. Persistence and Learning: Success Factors of Taiwanese Firms in International Markets. J. Int. Mark. 2009, 17, 39-54. [CrossRef]

49. Kilduff, M.; Angelmar, R.; Mehra, A. Top Management-Team Diversity and Firm Performance: Examining the Role of Cognitions. Organ. Sci. 2000, 11, 21-34. [CrossRef]

50. Bantel, K.A.; Jackson, S.E. Top management and innovations in banking: Does the composition of the top team make a difference? Strat. Manag. J. 1989, 10, 107-124. [CrossRef]

51. Salloum, C.; Jabbour, G.; Mercier-Suissa, C. Democracy Across Gender Diversity and Ethnicity of Middle Eastern SMEs: How Does Performance Differ? J. Small Bus. Manag. 2019, 57, 255-267. [CrossRef]

52. Hoogendoorn, S.; Oosterbeek, H.; Van Praag, M. The Impact of Gender Diversity on the Performance of Business Teams: Evidence from a Field Experiment. Manag. Sci. 2013, 59, 1514-1528. [CrossRef]

53. Van Der Vegt, G.S.; Bunderson, J.S. Learning and Performance in Multidisciplinary Teams: The Importance of Collective Team Identification. Acad. Manag. J. 2005, 48, 532-547. [CrossRef]

54. Moon, K.-K.; Christensen, R.K. Realizing the Performance Benefits of Workforce Diversity in the U.S. Federal Government: The Moderating Role of Diversity Climate. Public Pers. Manag. 2019, 49, 141-165. [CrossRef]

55. Jehn, K.A.; Northcraft, G.B.; Neale, M.A. Why Differences Make a Difference: A Field Study of Diversity, Conflict, and Performance in Workgroups. Adm. Sci. Q. 1999, 44, 741. [CrossRef]

56. Cox, D.R. Some Remarks on Overdispersion. Biometrika 1983, 70, 269-274. [CrossRef]

57. Cummings, J.N.; Kiesler, S.; Bosagh Zadeh, R.; Balakrishnan, A.D. Group Heterogeneity increases the Risks of Large Group Size: A Longitudinal Study of Productivity in Research Groups. Psychol. Sci. 2013, 24, 880-890. [CrossRef]

58. World Intellectual Property Organization (WIPO). Patent Cooperation Treaty Yearly Review 2017-The International Patent System; World Intellectual Property Organization: Geneva, Switzerland, 2017.

59. Trajtenberg, M. Patents, Citations and Innovations: Tracing the Links; U.S. National Bureau of Economic: Cambridge, MA, USA, 1987.

60. Cho, Y.; Han, Y.; Hwang, J.; Yu, J.; Kim, S.; Lee, C.; Lee, S.; Yi, K. Identifying Technology Opportunities for Electric Motors of Railway Vehicles with Patent Analysis. Sustainability 2021, 13, 2424. [CrossRef]

61. Phelps, C.C. A Longitudinal Study of the Influence of Alliance Network Structure and Composition on Firm Exploratory Innovation. Acad. Manag. J. 2010, 53, 890-913. [CrossRef]

62. Roessner, J.D. Technology Transfer', Science and Technology Policy in the US, A Time of Change; Longman: London, UK, 2000.

63. Cowan, R.; Zinovyeva, N. University effects on regional innovation. Res. Policy 2013, 42, 788-800. [CrossRef]

64. Blau, P.M. Inequality and Heterogeneity: A Primitive Theory of Social Structure; Free Press: New York, NY, USA, 1977.

65. Catozzella, A.; Vivarelli, M. The Catalysing Role of In-House R\&D in Fostering Complementarity Among Innovative Inputs. Ind. Innov. 2014, 21, 179-196. [CrossRef]

66. Gao, Y.; Hu, Y.; Liu, X.; Zhang, H. Can public R\&D subsidy facilitate firms' exploratory innovation? The heterogeneous effects between central and local subsidy programs. Res. Policy 2021, 50, 104221. [CrossRef]

67. Krueger, R.A.; Casey, M.A. Focus Groups: A Practical Guide for Applied Research; U.S. Sage Publications: Thousand Oaks, CA, USA, 2009.

68. Østergaard, C.R.; Timmermans, B.; Kristinsson, K. Does a different view create something new? The effect of employee diversity on innovation. Res. Policy 2011, 40, 500-509. [CrossRef] 